\title{
Single-centre experience of catheter ablation for arrhythmias in grown-up congenital heart disease
}

\author{
(C) Vedran Pašara*, \\ DIvan Prepolec, \\ DBorka Pezo-Nikolić, \\ (DDavor Puljević, \\ (DDavor Miličić, \\ (D)Vedran Velagić
}

University of Zagreb School of Medicine, University Hospital Centre Zagreb, Zagreb, Croatia

\section{RECEIVED:}

December 14, 2020

ACCEPTED:

December 18, 2020

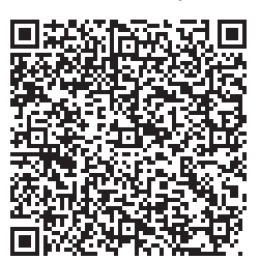

$\square$ Cardiologia Croatica 2021;16(1-2):64.
KEYWORDS: grown-up congenital heart disease, arrhythmias, catheter ablation procedures. CITATION: Cardiol Croat. 2021;16(1-2):64. | https://doi.org/10.15836/ccar2021.64

*ADDRESS FOR CORRESPONDENCE: Vedran Pašara, Klinički bolnički centar Zagreb, Kišpatićeva 12, HR-10000 Zagreb, Croatia. / Phone: +385-1-2367-466 / E-mail: vedran.pasara@gmail.com

ORCID: Vedran Pašara, https://orcid.org/0000-0002-6587-2315 • Ivan Prepolec, https://orcid.org/0000-0001-5870-202X Borka Pezo-Nikolić, https://orcid.org/0000-0002-0504-5238 • Davor Puljević, https://orcid.org/0000-0003-3603-2242 Davor Miličić, https://orcid.org/0000-0001-9101-1570 • Vedran Velagić, https://orcid.org/0000-0001-5425-5840

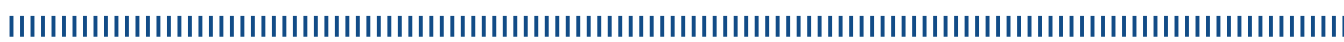

Arrhythmias are the main cause of morbidity and hospital visits for grown-up congenital heart (GUCH) patients. Supraventricular arrhythmias are the most frequent problem. Although usually not harmful in the general population, they can be severely compromising in GUCH patients. The low success rate of antiarrhythmic drugs in GUCH patients is well-recognized. Therefore, electrophysiologists play an important role in the diagnostics and treatment of rhythm disturbances in GUCH patients. ${ }^{1,2}$ In our centre, 13 GUCH patients underwent catheter ablation procedures from January 2015 to December 2020. There were six patients with atrial septal defect (ASD), two patients with tetralogy of Fallot (ToF), two with Ebstein anomaly, one with transposition of the great arteries, one with ventricular septal defect (VSD), and one with dextrocardia. A successful radiofrequency (RF) ablation of the cavotricuspid isthmus (CTI) was performed in five ASD patients, one patient with ToF, and eventually in a patient with VSD. The same procedure was unsuccessful in a patient with transposition of the great arteries. RF ablation for AVNRT was successfully performed in one patient with ASD, one patient with Ebstein anomaly, and a patient with dextrocardia. RF ablation of atrial tachycardia in another patient with Ebstein anomaly was discarded due to the high risk of iatrogenic AV node ablation. Another patient with ToF underwent only an electrophysiology study. In conclusion, the most common arrhythmia in our GUCH patients was CTI-dependent atrial flutter which was easily treated with a high success rate.

LITERATURE IIIIIIIIIIIIIIIIIIIIIIIIIIIIIIIIIIIIIIIIIIIIIIIIIIIIIIIIIIIIIIIIIIIIIIIIIIIIIIIIIIIIIIIIIIIIIIIIIIIIIIIIII

1. Dipen S. Ventricular arrhythmias in congenital heart disease: how can the electrophysiologist help? Cardiovascular Medicine. 2017;20(02):27-35. https://doi.org/10.4414/cvm.2017.00459

2. Tavera M, Foresti S, Cappato R. Arrhythmia in Congenital Heart Disease. European Cardiovascular Disease. 2007;3(1):110-2. https://doi.org/10.15420/ecr.2007.01.110 